\title{
The relative influence of service quality dimensions on perceptions of service quality in the banking industry
}

\author{
Christo Boshoff \\ Department of Business Economics, Vista University, Private Bag X613, Port Elizabeth 6000, Republic of South Africa \\ Gerhard Mels* \\ Department of Mathematical Statisics, University of Port Elizabeth, P.O. Box 1600, Port Elizabeth 6000, Republic of South Africa \\ Deon $\mathrm{Nel}$ \\ Department of Business Management, Rand Afrikaans University, P.O. Box 524, Johannesburg 2000, Republic of South Africa
}

Received July 1992, accepted September 1993

\begin{abstract}
Quality is an extremely difficult concept to define, describe and measure. Consequently, few academics and authors have attempted to model it and research findings on its influence on key business variables such as profitability and market share are confusing and inconclusive. These problems are compounded in the service sector where the use of objective measures of quality is almost impossible. In this study the pioneering work of Parasuraman, Zeithaml and Berry on service quality is used as framework to investigate the relative influence of service quality dimensions on overall perceptions of service quality in the banking industry. The empirical results show that empathy, assurance and reliability are the service quality dimensions which exert the most influence on consumers' evaluations of overall service quality.
\end{abstract}

Gehalte (kwaliteit) is ' $n$ begrip wat besonder moeilik is om te definieer, te omskryf of te meet. Die gevolg is dat min navorsers nog gepoog het om gehalte te modelleer en die navorsingsbevindinge or die invloed van gehalte op belangrike besigheidsveranderlikes soos winsgewendheid en markaandeel is verwarrend en dikwels onoortuigend. Hierdie probleme word selfs in 'n groter mate in die dienstesektor ondervind, waar die gebruik van objektiewe gehaltestandaarde byna onmoontlik is. In hierdie studie word die baanbrekerswerk van Parasuraman, Zeithaml en Berry as raamwerk gebruik om die relatiewe invloed van diensgehalte-dimensies op persepsies van algehele diensgehalte in die bankbedryf, te evalueer. Die empiriese resultate toon dat empatie (empathy), versekering (assurance) en betroubaarheid (reliability) die diensgehalte-dimensies is wat die grootste invloed op verbruikers se algehele evaluering van diensgehalte uitoefen.

*To whom correspondence should be addressed.

\section{Introduction}

Service firms have repeatedly been cautioned about the importance of quality to modern-day consumers (Bröh, 1982: 1; Moss \& Richardson, 1985: 7; Rabin, 1983: 12; Carvin, 1988: 216; Barker, 1990). Quality impacts on both buyingdecisions and on possible brand loyalty (Jacoby, Olson \& Haddock, 1971: 578). Marketers have accordingly begun to use quality as a competitive weapon (Townsend \& Gebhard,, 1986: 1; Garvin, 1984: 25; Leonard \& Sassu, 1982: 164). Unfortunately existing theory on the role of quality in the business environment is inconclusive. A possible reason is that research on quality and its relevance for business firms has been hampered by the lack of a generally acceptable definition of the concept. The result is that empirical work on the influence of quality on key business areas has yielded inconsistent and often conflicting findings. The research has concentrated mainly on the relationship between quality and other key business variables such as profitability, costs, prices, market share, productivity and advertising. Although not absolutely conclusive, research suggests, however, that there is a relationship between business success and the quality production and marketing of quality products and services. In other words, 'quality impacts on the bottom line' (Garvin, 1988: 69).

\section{Defining quality}

Quality is, in the words of Garvin (1988: xi), 'an unusually slippery conceph, easy to visualize and yet exasperatingly difficult to describe'. Some authors have attempted a definition (amongst others Bröh, 1982: 3-6; Parry, 1973: 15; Crosby, 1979: 17). Juran (1988: 4-5), on the other hand, is of the opinion that the concept 'quality' cannot be described adequately in a few words.

Garvin (1988: 39-46), in a review of previous attempts to define quality, has concluded that the problem surrounding a definition of quality, is that of coverage. Quality is studied in four disciplines (philosophy, economics, marketing, and operations management) and the result has been a host of competing perspectives, each based on a different analytical framework and employing its own terminology. According to Garvin (1988: 39-46) five principal approaches to defining quality can be distinguished from these multi-disciplinary approaches:

1. The transcendent approach claims that quality cannot be defined precisely; that it is a simple, unanalyzable property we learn to recognise only through experience. An example of such a definition is:

'Quality is neither mind nor matter, but a third entity independent of the two ... even though quality cannot be defined, you know what it is'.

2. The product-based approach views quality as a precise and measurable variable. An example of such a definition is:

'Quality refers to the amounts of unpriced attributes contained in each unit of the priced attribule'. 
3. The manufacturing-based approach considers conformity to pre-determined specifications and standards as crucial, and regards deviations as a reduction in quality. An example of such a definition is:

'Quality (means) conformance to requirements'.

4. The value-based approach defines quality in terms of costs and prices, that is, product conformance to specifications at an acceptable price or cost. An example of such a definition is:

'Quality is the degree of excellence at an acceptable price and the control of variability at an acceptable cost'.

Garvin (1988: 48) concludes that none of the approaches is perfect - each is vague and imprecise when it comes to describing the basic elements of product quality, yet, each could be of value during appropriate stages of a product's development process. In fact, as Garvin (1984: 29) points out, reliance on a single definition is a frequent source of unnecessary problems.

It is clear that there are almost as many definitions of quality as there are authors on the subject. A critical analysis (from a marketing perspective) of the debate surrounding an acceptable definition of quality does highlight a number of important facts. Firstly, the importance of quality is emphasized. If quality is lacking, in the words of Townsend \& Gebhardt (1986: 4-5) 'no sale will occur'. Secondly, the lack of consensus among those who have attempted to define the concept has serious implications for all research which involves quality considerations. Thirdly, the importance of consumer needs and preferences is stressed, even though some commentators have criticized the fact that, initially at least, this aspect was neglected by many who attempted to define quality (Shetty, 1988: 33; Townsend \& Gebhardt, 1986: 4).

Perceptions are an important consideration in the debate about what constitutes quality. Even when quality is defined as conformance to requirements (Crosby, 1979) or as incidence of internal and external failures (Garvin, 1988), the definitions are hardly objective, as the specifications themselves are based on the perceptions of managers rather than consumers (Zeithaml, 1988: 5). Managers' perceptions of quality may differ considerably from what consumers regard as quality. It is for this reason that Zeithaml (1988) suggests the use of perceived quality (what the consumer regards as quality) for definitional purposes rather than product-based, manufacturing-based or objective quality-hased attempts to define quality,

Quality seems to be a multi-dimensional concept which may have different meanings for different industries and different disciplines. It appears to be impossible to capture the essence of the concept in a few words and it is possibly even undesirable to do so. A possible alternative may be to describe quality in terms of characteristics or dimensions rather than to attempt to define it in a close-ended manner.

\section{Quality in the services sector}

The difficulty of defining and describing the construct 'quality' and its relevance for business firms has been a central theme in this study. The manufacturing sector's difficulties in defining quality are compounded in the service sector. The marketer of a service who is concemed with service quality, faces extensive problems because:

- Services are intangible and consumers have few, if any, cues from which to deduce quality (Zeithaml, 1981: 186).

- Services are often produced in association with the customer during employee-customer interaction (the service encounter), which makes the standardization of service quality almost impossible. In addition, the quality of the service encounter will determine the quality of the total service design (Shostack, 1985: 244; Bowen \& Schneider, 1985: 128-129).

- Services are often produced and consumed simultaneously, with the result that prospective buyers cannot, or have limited opportunities to evaluate quality prior to purchasing a service (Broh, 1982: 164 and 180; Berry, Zeithaml \& Parasuraman, 1985: 47).

These problems have made the use of objective measures of service quality almost impossible. Alternative means of measuring quality in services have had to be considered. It is doubtful, however, whether any real objective quality exists - even in the goods sector. Even if quality standards or quality specifications for service delivery are laid down, they are likely to be subjective as they are the result of what is perceived by someone (probably a manager) to be quality. Bowen \& Schneider (1985: 140) suggest that customers are in the best position to evaluate quality because of their interaction with employees in the service encounter. Consequently, Parasuraman, Zeithaml \& Berry (1988: 13) have proposed that service quality should be measured in terms of what customers regard as quality, so-called perceived quality, rather than in terms of devised objective or technical service quality specifications.

\section{Measuring service quality}

Parasuraman et al. (1988) based their attempts to measure service quality on an earlier conceptual model of service quality (see Parasuraman, Zeithaml \& Berry, 1985). Their reasoning is based on the assumption that services differ from physical products in important respects. As services are intangible, heterogeneous, and production/delivery and consumption cannot be separated, they conclude that service quality can not be measured objectively. In other words, service quality can be measured only in terms of subjective and relative criteria, such as consumer perceptions of quality.

Perceived quality, the central tenent of the Parasuraman et al. (1985) model and their means of measuring service quality, is the consumer's judgement of overall quality. Perceived quality differs from objective quality in that it is an attitude which is related to, but not identical to, satisfaction. Furthermore, perceived quality is the result of a comparison between predelivery expectations and perceived actual service.

Parasuraman et al. (1988) believe that quality on the one hand, involves a global evaluation (or attitude) about the superiority of a service. Satisfaction, on the other hand, relates to a specific transaction. In other words, a customer may be satisfied with a particular service but may not regard the service firm as being of high quality. The concepts of service quality and satisfaction are related in the sense that 
continuous incidents of satisfaction may lead, in time, to perceptions of service quality. Satisfaction is then defined as: '... the degree and direction of discrepancy between consumers' perceptions and expectations' (Parasuraman et al., 1988: 17). Expectations are viewed as a consumer's prediction of the probable outcomes of a service encounter.

Parasuraman et al. (1988) concluded that consumers used ten criteria to evaluate service quality irrespective of the service being evaluated (the so-called dimensions of service quality). These dimensions are (Parasuraman et al., 1985: 47): reliability, responsiveness, competence, access, courtesy, communication, credibility, security, understanding/ knowing the customer, and tangibles.

Further investigations, including empirical testing, led Parasuraman et al. (1988) to conclude that the original ten dimensions along which consumers evaluate service quality could be reduced to five. These dimensions are:

Tangibles: $\quad$ refers to physical facilities, equipment and appearance of personnel;

Reliability: refers to the ability to perform a promised service dependably and accurately;

Responsiveness: refers to the firm's willingness to provide customers with prompt service and assist them where necessary;

Assurance: $\quad$ refers to the knowledge, skill and, courtesy of employees and their ability to inspire trust and confidence; and

Empathy: is characterized by caring and the degree to which customers receive individualized service from employees.

The final twenty-two items (measuring these five dimensions) were then divided into two sections. Section A consists of twenty-two statements relating to expectations of service delivery. Section B addresses the same twenty-two issues, but provides for an evaluation of actual service delivery. In other words, for every item or dimension, a respondent will be able to indicate how important he considers the item (Section A) and the manner in which a service firm known to the respondent, performs the item (Section B). The difference between the total score for expectations (Section A) and the total score for actual performance (Section B) will then be a measure of the level of perceived service quality. Parasuraman et al. (1988) named this measuring instrument, SERVQUAL.

\section{Methodology}

A probability sampling technique was used in this study. For this purpose, the address lists of the television licence holders of the South African Broadcasting Corporation served as sampling frame. A systematic random sample was drawn, following a random start. The total sample size was 650. The study used a mail survey. In total 180 useable questionnaires were returned which yields a response rate of $27.7 \%$. In Table 1 the nature of the respondent group is described in terms of the four demographic variables: gender, age, level of education and home language.

The SERVQUAL instrument was used to measure the evaluations of service quality dimensions in the banking industry amongst the sample of 180 respondents. In addition, respondents were asked to evaluate the quality of service they receive from their banks on a four point scale of poor/fair/good/excellent. The complete set of questionnaire items are provided in Appendix A. This overall evaluation of quality (Q) served as dependent variable in this study.

The aim of this research was to address the following two objectives, namely

1. To determine whether or not the original 22 evaluation statements represent measurements of the five service quality dimensions: tangibles, reliability, responsiveness, assurance and empathy as suggested by Parasuraman et al. (1988).

2. To determine the relative influence (if any) of the consumers' service quality dimensions on their overall service quality evaluation of the banking industry.

The first objective was addressed by means of a factor analysis of the original 22 evaluation statements. These results were then used to construct a causal model which was subjected to a path analysis with latent variables to address the second objective.

Table 1 Demographic composition of the sample of respondents

\begin{tabular}{|c|c|c|c|c|}
\hline Gender & $\mathbf{P}$ & $\%$ & & \\
\hline Male & 123 & 68.3 & & \\
\hline Fermale & 57 & 31.7 & & \\
\hline Total & 180 & 100.0 & & \\
\hline Age & $\mathbf{P}$ & $\%$ & & \\
\hline $15-19$ & $\mathbf{0}$ & 0.00 & & \\
\hline $20-24$ & 5 & 2.80 & & \\
\hline $25-34$ & 41 & 22.8 & & \\
\hline $35-44$ & 46 & 25.2 & & \\
\hline $45-54$ & 30 & 16.7 & & \\
\hline $55-64$ & 34 & 18.9 & & \\
\hline $65-74$ & 17 & 9.40 & & \\
\hline $75+$ & 7 & 3.90 & & \\
\hline Total & 180 & 100.0 & & \\
\hline \multicolumn{3}{|c|}{ Level of education } & $\mathbf{P}$ & \$ \\
\hline \multicolumn{3}{|c|}{ Sid 9 or lower } & 26 & 14.4 \\
\hline \multicolumn{3}{|c|}{ Std 10 or equivalent } & 53 & 29.4 \\
\hline \multicolumn{3}{|c|}{ Matric plus diploma/s } & 50 & 27.9 \\
\hline \multicolumn{3}{|c|}{ Matric plus degree/s } & 51 & 28.3 \\
\hline \multicolumn{3}{|l|}{ Totals } & 180 & 100.0 \\
\hline \multicolumn{3}{|c|}{ Home language } & $\mathbf{r}$ & $\%$ \\
\hline \multicolumn{3}{|c|}{ Afrikaans } & 96 & 53.3 \\
\hline \multicolumn{3}{|l|}{ English } & 82 & 45.6 \\
\hline \multicolumn{3}{|c|}{ European } & 2 & 1.10 \\
\hline \multicolumn{3}{|l|}{ Total } & 180 & 100.0 \\
\hline
\end{tabular}




\section{Emplrical results}

To investigate the first objective, a principal factor analysis was performed on the sample correlation matrix of the original 22 evaluation statements (from SERVQUAL). The extraction of five factors was specified to facilitate comparison with the five factor structure found by Parasuraman et al. (1988). The computer program BMDP4M (Frane, Jennrich \& Sampson, 1990) was used, by specifying a Direct Quartimin oblique rotation (Jennrich \& Sampson, 1966) of the unrotated factor matrix. The resulting rotated factor matrix is shown in Table 2.

Table 2 Rotated factor loadings ${ }^{1}$ for evaluated service quality dimensions

\begin{tabular}{lrrrrr}
\hline & Factor 1 & Factor 2 & Factor 3 & Factor 4 & Factor 5 \\
\hline Item 1 & -0.003 & 0.424 & 0.215 & -0.003 & \multicolumn{1}{c}{0.042} \\
Item 2 & -0.068 & 0.939 & -0.057 & 0.036 & -0.066 \\
Ilem 3 & 0.000 & 0.544 & 0.056 & 0.078 & 0.086 \\
Item 4 & 0.072 & 0.731 & -0.031 & 0.051 & 0.090 \\
Item 5 & 0.251 & -0.062 & 0.385 & 0.153 & 0.170 \\
Item 6 & 0.289 & 0.133 & 0.276 & 0.202 & -0.040 \\
Item 7 & -0.083 & -0.030 & 0.595 & 0.208 & 0.216 \\
Item 8 & 0.100 & 0.110 & 0.207 & 0.091 & 0.337 \\
Item 9 & -0.024 & 0.052 & 0.666 & 0.067 & 0.063 \\
Item 10 & 0.423 & 0.174 & -0.004 & -0.060 & 0.365 \\
Item 11 & 0.342 & 0.069 & -0.025 & 0.423 & 0.251 \\
Item 12 & 0.154 & 0.131 & -0.063 & 0.707 & -0.046 \\
Item 13 & 0.499 & 0.080 & 0.027 & 0.106 & 0.169 \\
Item 14 & 0.316 & 0.170 & 0.478 & -0.075 & -0.140 \\
Item 15 & 0.096 & 0.169 & 0.542 & 0.037 & 0.016 \\
Item 16 & -0.044 & 0.073 & 0.213 & 0.615 & -0.001 \\
Item 17 & 0.307 & 0.180 & 0.092 & -0.005 & 0.072 \\
Item 18 & 0.750 & -0.022 & 0.039 & 0.108 & -0.126 \\
Item 19 & 0.825 & 0.005 & 0.047 & -0.000 & -0.018 \\
Item 20 & 0.407 & 0.033 & 0.111 & 0.158 & 0.277 \\
Item 21 & 0.474 & -0.023 & -0.033 & 0.118 & 0.143 \\
Item 22 & 0.003 & 0.114 & 0.196 & 0.029 & 0.463 \\
\hline & & & & \\
\hline
\end{tabular}

1. Loadings $>0.40$ were considered as significant.

2. Original SERVQUAL items were all transformed (recoded) to positive items.

The factor structure pertaining to evaluations of their banks by respondents shown in Table 2, reveals that all the items reported by Parasuraman et al. (1988) to measure empathy (except item 22) loaded on Factor 1, and those supposed to measure tangibles, loaded on Factor 2. In addition, items 10 and 13 which are supposed to measure responsiveness, also loaded on Factor 1. Although this differs from the findings of Parasuraman et al. (1988), a careful study of items 10 and 13 reveals that they can be interpreted as measurements of empathy. Only two of the items expected to measure reliability ( 7 and 9), however, loaded on Factor 3, while two items (14 and 15) expected to measure assurance, also loaded on Factor 3. Although reasons for this deviation are purely speculative, it must be pointed out that items 14 and 15 both refer to a sense of trust between client and bank employee. Items 14 and 15 may, therefore, not have been completely distinguishable from the reliability items. An example is item 7 (a reliability item) which refers to the need for bank employees to be dependable. To the respondents dependability may not have seemed that far removed from reliability. Items 11,12 and 16 loaded on Factor 4 and a careful study of the contents of these items suggests that they measure responsiveness. Since only item 22 loaded on Factor 5, an interpretation of this factor is not feasible or sensible.

Of the five factors listed in Table 2, Factor 1 (empathy) explains $70.8 \%$ of the variation in the data space while the five factors cumulatively account for $91.6 \%$ of the variation.

After a careful study of the factor analysis results (reported in Table 2) the empirical factor structure reported in Table 3 was found to be a sensible structure to enable the construction of a causal model.

The latent variables identified in Table 3 were used to construct a causal model to address the second objective for tangibles, assurance/reliability, responsiveness and empathy, i.e. What is the relative influence of consumers' evaluations of tangibles, assurance/reliability, responsiveness and empathy on their overall evaluation of the service quality in the banking industry? The path diagram (Bollen, 1989; Mels, 1988) which depicts this causal model is shown in Figure 1.

Items measuring evaluated service quality may be grouped into items measuring evaluated tangibles (EVTANG), items measuring evaluated assurance/reliability (EVASS/ REL), items measuring evaluated responsiveness (EVRESP) and items measuring evaluated empathy (EVEMP). This groliping of the items measuring evaluated service quality is

Table 3 Empirical factor structure for causal modelling

\begin{tabular}{ll}
\hline Factor/latent variable & Measurements \\
\hline Tangibles & Items $1,2,3,4$ \\
Assurance/reliability & Items $7,9,14,15$ \\
Responsiveness & Items $11,12,16$ \\
Empathy & Items $10,13,18,19,20,21$ \\
\hline
\end{tabular}

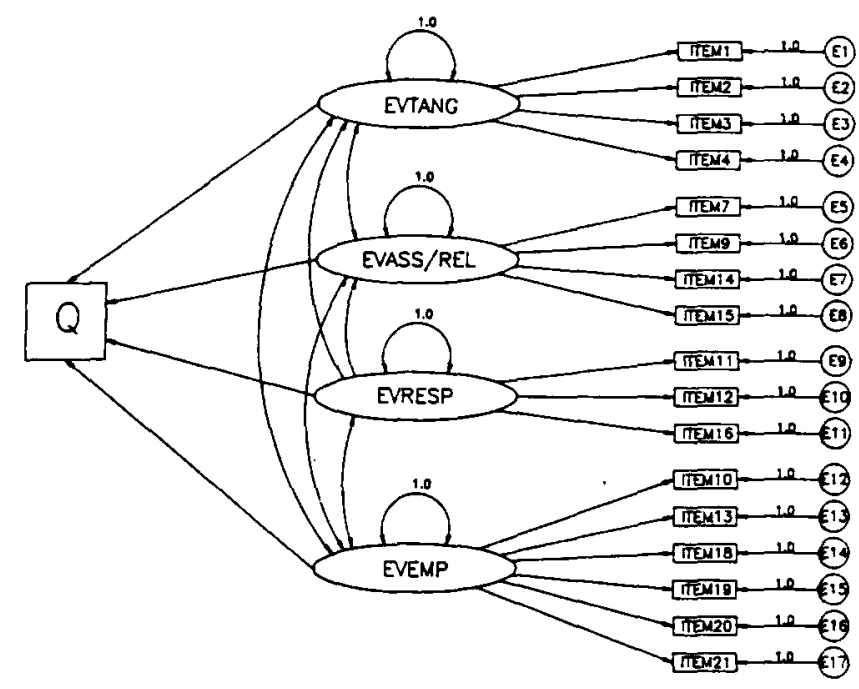

Figure 1 Causal model for evaluated service quality 
shown in Figure 1. Figure 1 shows that the measurements of craluated angibles are TTEM1, ITEM2, TEM3 and ITEM4. ITEM7, TTEM9. TTEM14 and ITEM15 are used as measurements of evaluaced assurancefreliability, while evahamod responsiveness is measured by ITEM11. ITEM12 and TEM16. Evaluated empathy is measured by ITEM10, ITEM 13, ITEM18, ITEM 19, ITEM20 and ITEM21. The corresponding measurement emors are denoted by El-El?. In adtition, the madd depictod in Figure 1 suggests that overall pality (Q) is caused by evaluated tangibles (EVTANG), evaluated ascuranoe/retivitity (EVASS/REL), evaluatod responsiveness (EVRESP) and evaluatod cmpathy (EVEMP). The arror cerm oorresponding to this regression oquation is denomod by ZI.

Toin 4 Sample correlation matrix of the obsenved veriables in Figure 1

\begin{tabular}{|c|c|c|c|c|c|c|}
\hline & hen I & hom 2 & $\operatorname{han} 3$ & hem 4 & hein 7 & $\ln 9$ \\
\hline Jeem ! & 1.060 & & & & & \\
\hline $\operatorname{lnem} 2$ & 0.495 & 1.600 & & & & \\
\hline $\operatorname{lem} 3$ & 0.422 & 0.517 & 1.000 & & & \\
\hline $\operatorname{lom} 4$ & 0.458 & 0.694 & 0.550 & 1.600 & & \\
\hline nem 7 & 0.376 & 0.357 & 0.399 & 0.021 & 1.000 & \\
\hline Drow 9 & 0.561 & 0.338 & 0.351 & 0.429 & 0.561 & 1.000 \\
\hline lom 10 & 0.328 & 0.564 & 0.305 & 0.523 & 0.997 & 0.362 \\
\hline hem 11 & 0.349 & 0.429 & 0.434 & 0.464 & 0.526 & 0.390 \\
\hline $\ln 12$ & 0.279 & 0.408 & 0.376 & 0.484 & 0.424 & 0.400 \\
\hline $\operatorname{lnom} 13$ & 0.955 & 0.314 & 0.559 & 0.409 & 0.399 & 0.360 \\
\hline Itwem 14 & 0.309 & 0.428 & 0.350 & 0.401 & 0.432 & 0.163 \\
\hline leem 15 & 0.945 & 0.493 & 0.424 & 0.464 & 0.551 & 0.537 \\
\hline 160 & 0.954 & 0.382 & 0.402 & 0.126 & 0.499 & $0.44]$ \\
\hline hem 18 & 0.282 & 0.299 & 0.360 & 0.366 & 0.318 & 0278 \\
\hline hom 19 & 0.249 & 0.303 & 0.365 & 0.378 & 0.335 & 0.302 \\
\hline $\operatorname{tram} 20$ & 0.329 & 0.357 & 0.354 & 0.06 & 0.437 & 0.424 \\
\hline $\ln 21$ & 0.214 & 0.250 & 0.217 & 0.288 & 0.279 & 0.277 \\
\hline \multirow[t]{2}{*}{$Q$} & 0.995 & 0.373 & 0.960 & 0.435 & 0.59 & $0.4 \times 4$ \\
\hline & Jeen 10 & $\mathrm{kem} 11$ & Inem 12 & $\operatorname{bom} 13$ & hem 14 & hom 15 \\
\hline $\operatorname{lem} 10$ & 1.000 & & & & & \\
\hline ham 11 & 0.586 & 1.600 & & & & \\
\hline Juen 12 & 0.402 & 0.635 & 1.600 & & & \\
\hline leem 13 & 0.456 & 0.626 & 0.477 & 1.600 & & \\
\hline ltem 14 & 0.949 & 0.427 & 0.338 & 0.409 & 1.00 & \\
\hline $\operatorname{lom} 15$ & 0.408 & 0.458 & 0.416 & 0.466 & 0.535 & 1.600 \\
\hline hem 16 & 0.325 & 0.581 & 0.591 & 0.415 & 0.374 & 0.444 \\
\hline $\operatorname{lom} 18$ & 0.480 & 0.532 & 0.474 & 0.5604 & 0.449 & 0.292 \\
\hline Itwen 19 & 0.495 & 0.562 & 0.471 & 0.592 & 0.426 & 0.443 \\
\hline tem 20 & 0.537 & 0.617 & 0.498 & $0.5 \times 7$ & 0.357 & 0.481 \\
\hline $\operatorname{lom} 21$ & 0.445 & 0.496 & 0.028 & 0.415 & 0.325 & 0.270 \\
\hline \multirow[t]{2}{*}{$\boldsymbol{Q}$} & 0.476 & 0.539 & 0.025 & 0.494 & 0.386 & 0.401 \\
\hline & $1 \mathrm{lum} 16$ & $\operatorname{lem} 18$ & Inemitg & $\ln =0$ & $\operatorname{trem} 21$ & $\mathbf{Q}$ \\
\hline in 16 & 16000 & & & & & \\
\hline Inan 78 & 0.581 & 1,000 & & & & \\
\hline $\ln 19$ & 0.978 & $0 x 33$ & $1 \times 00$ & & & \\
\hline $\lim 20$ & 0.492 & 0.40 & 0.579 & 1.600 & & \\
\hline $\ln 21$ & 0.288 & 0.376 & D.481 & 0.446 & 1.600 & \\
\hline$Q$ & 0.405 & 0.573 & 0.408 & 0.501 & 0.377 & 1600 \\
\hline
\end{tabular}

The theoretical model shown in Figure 1 was fitted to the data by using the computer program RAMONA (Browne Mels, 1990). This analysis was performed on the sample correlation matrix shown in Table 4 and the results are re. parted in Figure 2

Figure 2 shows that none of the four service quality dimensions has a statistically significant influence (at the $5 \%$ level of significance) on respondenes overall evaluations of service quality in the banking industry. The influences of evaluated empachy and evaluaved ascurance/relibbility on service quality evaluation (Q) do approsch the significan cut-off point, however.

To establish the exient to which the hypothesized model provides an acoeptable fin to the dan, the measures of fit of the model have to be considered. Reading Table 5, the con fidence interval for the discrepancy function does not inclade zero as a lower bound. It must, therefore, be con cladod that the model (depicted in Figure 1) does not provide a perfoct fit to the data at the 95\% level of significance (Mets \& Koors, 1989: 145). This result is also suppored by the value of the chi-squed test statistic. However, the value of the Roa Mean Square Error of Approxintion (RMSEA) of 0.054 is less than 0.08 which suggests that the model provides a reascanble fit (Steiger \& Lind, 1980, Browne \& Mels, 1990). This resuly is supported by the fact that the poim estimate of the expected modified cross validation index (1.577) is smaller than the modified cross validation index for the saturated moded (1.911). It mat be kep in mind though, that the fit of the model plays a secondery role in the causal modelling matysis considend in this structy.

Due wo the stanl path coefficions for evelunted anjites (0.099) and evaluatod responsivoness (0.070), it was locided to fir a causal model in which the influences of these two incul variables on overall service qualicy are removed. The resulus of this malysis is shown in Figure 3. From Figure 3 in $\mathrm{cm}$ be sean that both the path coefficients for evaluned cuppothy $(0.382)$ as weil as for evalumed reliabilityfer surnace $(0.376)$ me stristically significant $(p<0.01)$. Sin the path coefficient bewoen $Q$ and evaluned onply

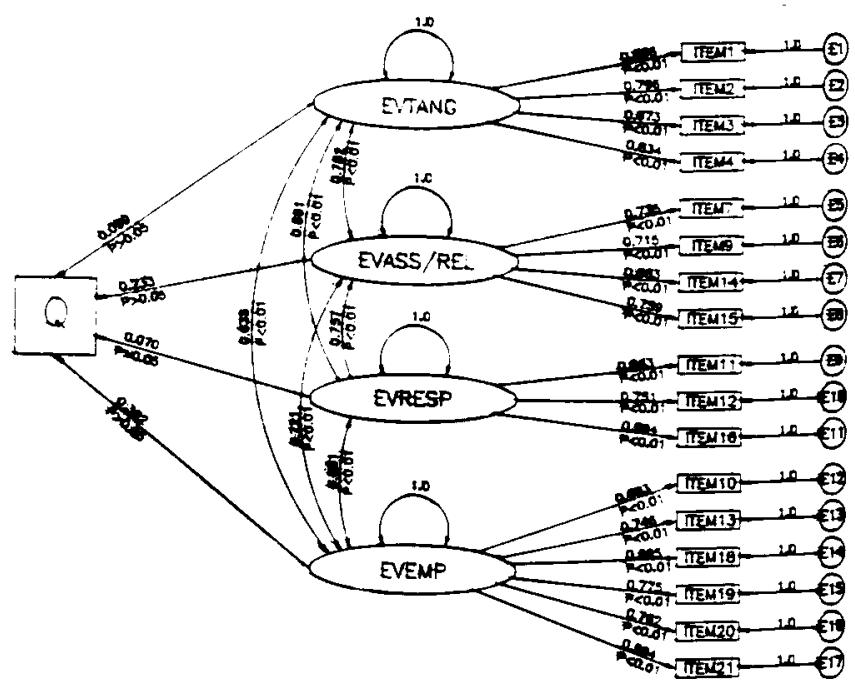

Rume 2 Cussi modid tor evaluned service quality: empirical to aules 
Table 5 Measures of fit of the causal model in Figure 1

\begin{tabular}{lc}
\hline Sample discrepancy function value & 1.074 \\
Estimate of population discrepancy function value & 0.370 \\
$90 \%$ Confidence interval for population discrepancy & \\
function value & $0.183-0.602$ \\
Root Mean Square Error of Approximation (RMSEA) & 0.054 \\
$90 \%$ Confidence interval for RMSEA & $0.038-0.069$ \\
Cross validation index (modified AIC) & 1.577 \\
Modified AIC for saturated model & 1.911 \\
Value of Chi-squared statistic for hypotheses of perfect fit & 192.3 \\
Exceedance probability of Chi-squared statistic & 0.000
\end{tabular}

(EVEMP) is the greatest, it appears that evaluated empathy is the service quality dimension which is the most important determinant of the overall service quality evaluation (Q).

From these results it appears that when respondents evaluate service quality in the banking industry as excellent, good, fair, or poor, they appear to be mainly influenced by empathy and assurance/reliability considerations.

Empathy refers to the ability of banks to provide clients with personal and individualized attention, the degree to which bank employees have their clients' best interests at heart and the extent to which banks have business hours which are convenient to their clients.

Assurance/reliability considerations include issues like the dependability of the bank, the accuracy of record-keeping, the degree to which bank employees can be trusted, and the degree to which services are performed when promised.

From the measures of fit of the model listed in Table 6 it is evident that although the hypothesis of a perfect fit is rejected, the reduced model does provide a reasonable fit to the data.

\section{Discussion}

With this study we have shown that empathy, assurance and reliability are the quality dimensions of importance to consumers' evaluation of service quality in the banking industry - a finding which concurs with those reported by Parasuraman et al. (1988: 31) and those reported by Evans \& Grant (1990: 17).

The concept of empathy refers to the degree of caring and to which clients receive individualized service from a bank's

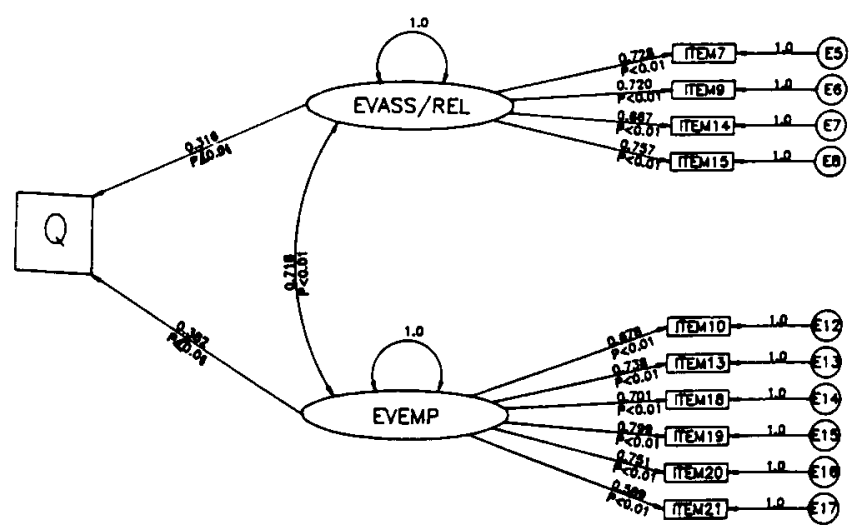

Figure 3 A reduced causal model for evaluated service quality: empirical results
Table 6 Measures of fit of the reduced causal model in Figure 3

\begin{tabular}{lc} 
Sample discrepancy function value & 0.377 \\
Estimate of population discrepancy function value & 0.142 \\
$90 \%$ Confidence interval for population discrepancy & \\
function value & $0.038-0.290$ \\
Root Mean Square Error of Approximation (RMSEA) & 0.058 \\
90\% Confidence interval for RMSEA & $0.030-0.083$ \\
Cross validation index (modified AIC) & 0.645 \\
Modified AIC for saturated model & 0.737 \\
Value of Chi-squared statistic for hypotheses of perfect fit & 67.41 \\
Exceedance probability of Chi-squared statistic & 0.008 \\
\hline
\end{tabular}

employees. In this study the following items were used as measurements of evaluated empathy, namely:

- My bank does not give me individual attention;

- My bank's employees do not give me individual attention;

- My bank's employees do not know what their clients' needs are;

- My bank does not have my best interests at heart;

- My bank does not tell clients exactly when services will be available; and

- My bank's employees are never too busy to respond to their customers' requests promptly.

It should be pointed out that although the final two items listed above usually refer to the responsiveness of banks and their employees, it can also be interpreted as empathy as found in this study.

The term reliability relates to a bank's performing services when promised, how sympathetic service banks are when clients experience problems, the bank's dependability, and the accuracy of a bank's record-keeping. Assurance refers to the knowledge, skill and courtesy of bank employees and their ability to inspire trust and confidence. In practice, it may be difficult for respondents to distinguish between these two concepts as found in this study. The items which are considered as measurements of assurance/ reliability are:

- I trust my bank's employees;

-I feel secure during my transactions with my bank;

- My bank is dependable; and

- My bank keeps its records accurately.

\section{Managerial Implications}

It should be noted that all four items used to measure assurance/reliability relate to service firm employees - the people customers come into contact with during the service encounter. This is also true for several items which were used to measure empathy. Consequenuly, the importance consumers attach to assurance, reliability and empathy in service delivery, confirms the importance of human interaction in service delivery and emphasizes the importance of services marketing techniques, such as internal marketing, in the pursuance of maximum service quality. 


\section{Acknowledgement}

The financial assistance provided by the Institute for $\mathrm{Re}$ search Development of the Human Sciences Research Council is hereby acknowledged. Any opinions expressed and the conclusions drawn are those of the authors and should not be attributed either to the Institute for Research Development or the Human Sciences Research Council.

\section{References}

Barker, J.A. 1990. The business of paradigms. Discovering the Future Video Series by Charthouse Learning Corporation.

Bollen, K.A. 1989. Structural equations with latent variables. New York: Wiley.

Berry, L.L., Zeithaml, V.A. \& Parasuraman, A. 1985. 'Quality counts in services, too', Business Horizons, May-June: 44-52.

Bowen, D.E. \& Schneider, B. 1985. 'Boundary-spanning-role employees and the service encounter: some guidelines for management and research'. In: Czepiel, J.A., Solomon, M.R. \& Suprenant. C.F. (eds). The service encounter: managing employee/customer interaction in service businesses. Lexington, Massachusetts: Lexington Books: 127-147.

Bröh, R.A. 1982. Managing quality for higher profits. New York: McGraw Hill.

Browne, M.W. \& Mels, G. 1990. RAMONA PC user's guide. Unpublished report. Pretoria: Human Sciences Research Council.

Crosby, P.B. 1979. Quality is free. New York: McGraw-Hill.

Evans, K.R. \& Grant, J.A. 1990. Managing sales performance of service personnel. Unpublished working paper. Tempe, Arizona: Arizona State University.

Frane, J., Jennrich, R.I. \& Sampson, P.F. 1990. 'P4M-Factor analysis'. In Dixon, W.J. \& Brown, M.B. (eds). BMDP statistical software manual, Volume 1 . Berkeley: University of California.

Garvin, D.A. 1984. 'What does product quality really mean?', Sloan Management Review, Vol. 26, No. 1: 25-43.

Garvin, D.A. 1988. Managing quality. New York: The Free Press.

Jacoby, J., Olson, J.C. \& Haddock, R.A. 1971. 'Price, brand name and product composition characteristics as determinants of perceived quality', Journal of Applied Psychology, Vol. 55, No. 6: 570-579.

Jennrich, R.I. \& Sampson, P.F. 1966. 'Rotation for simple loadings', Psychometrika. Vol. 31: 313-323.

Juran. J.M. 1988. Juran on planning for quality. New York: The Free Press.

Leonard, F.S. \& Sasser, W.E. 1982. 'The incline of quality', Harvard Business Review, Vol. 60, SeptemberOctober: 163-171.

Mels, G. 1988. A general system for path analysig with latent variables. Unpublislied M.Sc. Dissertation. Pretoria: University of South Africa.

Mels, G. \& Koorts, A.S. 1989. 'Causal models for various job aspects', SAIPA Journal of Public Administration. Vol. 24, No. 3: 144-156.

Moss, C.D. \& Richardson, B. 1985. 'Customer satisfaction - the key to successful and legally unfettered trading', European Jowrnal of Marketing. Vol. 19, No. 6: 5-11.

Parasuraman, A. 1986. Marketing research. Reading, Massachusetts: Addison-Wesley.

Parasuraman, A., Zeithaml, V.A. \& Berry, L.L. 1985. 'A conceptual model of service quality and its implications for future research', Journal of Marketing, Vol. 49, Fall: 41-50.
Parasuraman, A., Zeithaml, V.A. \& Berry, L.L. 1988. 'SERVQUAL: a multiple-item scale for measuring consumer perceptions of service quality', Journal of Retailing. Vol. 64, No. 1: 12-40.

Parry, V.G. 1973. The control of quality. London: McMillan Handbooks in Industrial Management.

Rabin J.H. 1983. 'Accent is on quality in consumer goods and services this decade', Marketing News, 4 March: 12.

Shetty, Y.K. 1988. 'Managing product quality for profitability', SAM Advanced Management Journal, Vol. 53, No. 4: 33-38.

Shostack, G.L. 1985. 'Planning the service encounter'. In Czepiel, J.A., Solomon, M.R. \& Surprenant, C.F. (eds). Managing employee/customer interaction in service businesses. Lexington, Massachusetts: Lexington Books: 243-253.

Steiger, J.H. \& Lind, J. 1980. Statistically based tests for the number of common factors. Paper presented at the annual meeting of the Psychometric Society, Iowa City, IA.

Townsend, P.L. \& Gebhardt, J.E. 1986. Commil to quality. New York: John Wiley.

Zeithaml, V.A. 1981. 'How consumer evaluation processes differ between goods and services'. In Donnelly, J.H. \& George, W.R. (eds). Marketing of services. Chicago, Illinois: American Marketing Association, Proceedings Sedes: 186-190.

Zeihaml, V.A. 1988. 'Consumer perceptions of price, quality, and value: a means-end model and synthesis of evidence', Journal of Marketing, Vol. 52, July: 2-22.

\section{Appendlx A Questionnaire items}

\section{A. Tangibles}

Item 1 My bank has modern equipment.

Item 2 My bank's physical facilities are visually appealing.

Item 3 My bank's employees are well dressed and appear neat.

Item 4 The appearance of my bank's physical facilities is in keeping with the type of services provided.

\section{B. Reliability}

Item 5 When my bank promises to do something by a certain time, they do so.

Item 6 When I have a problem, my bank is sympathetic.

Item 7 My bank is dependable.

Item 8 My bank provides its services at the times it has promised to do so.

Item 9 My bank keeps its records accurately.

C Responsiveness

Item 10 My bank does not tell clients exactly when services will be available.

Item 11 I do not receive prompt service from my bank's employees.

Item 12 My bank's employees are not always willing to help clients.

Item 13 My bank's employees are never too busy to respond to their clients' requests promptly.

\section{Assurance}

Item 14 I trust my bank's employees.

Item 15 I feel secure during my transactions with my bank.

Item 16 My bank's employees are polite.

Item 17 My bank's employees get adequate support from their managers to do their jobs well. 


\section{E. Empathy}

Item 18 My bank does not give me personal attention.

Item 19 My bank's employees do not give me personal altention.

Item 20 My bank's employees do not know what their clients' needs are.

Item 21 My bank does not have my best interests at hear.
Item 22 My bank does not bave busineas hours convenient to their clients.

F. Overall service quality

Q Evaluate the overall service of your bank:

Poor/Fair/Good/Excellent 